\title{
The Instructional Material Development Based on National Qualification Frame of Indonesia to Improve Technical Skills of Machine Technical Student
}

\author{
Robert Silaban ${ }^{1}$, Julaga Situmorang ${ }^{2}, \operatorname{Siman}^{3}$ \\ \{robertsilaban@unimed.ac.id. ${ }^{1}$, profjulagasitumorang@ gmail.com ${ }^{1}$, simannurhadi@yahoo.co.id $^{1}$ \} \\ Department of Mechanical Engineering, Univesitas Negeri Medan, Jalan Willem Iskandar Pasar V, \\ Medan 20221, Indonesia ${ }^{1,2,3}$
}

\begin{abstract}
The development of instructional material based on national qualification frame of Indonesia to improve technical skills of machine technical student is explained. The study is aimed to obtain instructional material which have high effectiveness. The instructional material is developed by conducting needs assessment of technical skills based on national qualification frame from varies sources (stakeholders), to arrange instructional material as a preliminary instructional material to be developed based on the needs assessment, and then conducting try out of that instructional material. For this study used Borg and Gall as a research method which combine by Dick, Carey and Carey model. The subject of this study are the student of Machine technical department Faculty of Engineering Universitas Negeri Medan. The subject of preliminary field testing are two experts in technical mechanical material, two experts in instructional design, two experts in instructional media, three students for one to one try out, twelve students for small group try out and twenty five students for field try out. The instrument employed in this study is a questionnaire, observation, and performance test that analyzed by using descriptive and inferential statistics. The finding of study are: (1) the quality of instructional material viewed from the expert in educational technologies is good, (2) in the one to one try out indicated that the product is good, (3) in the small group try out indicated that the product is good.
\end{abstract}

Keywords: : Instructional material development, technical skill, national qualification frame

\section{Introduction}

Conceptually, the competency-based curriculum can be recognized as one of the means for the implementation of the teaching and learning process in the classroom to provide and broaden students' horizons about knowledge, skills, and other basic values in hopes of being reflected in: the habits of thinking and acting. However, students have a very strong dependence on how he is treated by educators. That is, the success of students mastering vocational competencies is related to how educators practice the learning system in school.

On the other hand, weaknesses in the implementation of vocational competency learning stem from different perceptions between the implementing components ,and lack of ability to translate vocational competencies into teaching and learning operations, so that learning outcomes as a form of competence Vocational students have become weak or low. The main 
problem in the conceptual learning of vocational competence is how to relevance teaching materials with the Indonesian national qualification framework contained in the planning and readiness of teaching staff to manage their learning so that the desired competencies in the students themselves can be achieved and practically as far as the competencies of a teacher to provide and expand insight into applying it to classroom learning practices. This really needs to be developed in a teacher by developing his skills through vocational competence.

If the mechanism for managing vocational competence learning has gone as it should, which is carried out on the basis of insight, learning needs and objectives that enable students to think creatively and master the competencies contained in the curriculum, then knowledge and skills as a result of the implementation of teacher teaching can be found in acquisition of learning outcomes achieved by students. Thus the development of learning materials to improve vocational competence in the form of technical skills (technical skills), is one answer as an effort to improve student learning outcomes in vocational schools.

This is related to Unvesitas Negeri Medan 's flagship program found in the 2016-2017 Strategic Plan, one of which is Increasing Graduates Relevance through strengthening the implementation of competency-based curriculum, and the block system curriculum based on the Indonesian national qualification framework, one of which is the development of teaching materials and learning media. For the Department of Mechanical Engineering Education, will produce graduates who are able to carry out effective learning in Vocational Schools (SMK) in technology and engineering.

Competency demands from graduates of vocational schools in technology and engineering are technical skills in the field of machine element design technology. This means that the competency of the graduates of the Mechanical Engineering Universitas Negeri Medan Faculty of Mechanical Engineering Education Program is the technical skills in the design of machine elements as a minimum competency. Therefore, his learning in the Engineering Study Program of Mechanical Engineering Faculty Mechanical Engineering UniversitasNegeri Medan needs to be minimized with the learning needs of Vocational Education in Vocational High Schools, especially in the eyes of the teaching of machine element design..

The main problem in learning technology vocational competence conceptually is how to relevant teaching materials with the Indonesian National Qualification Framework contained in planning and readiness of the teaching staff to manage the learning to be achieved the desired competence in students, in this case, the student of Education Study Program Mechanical Engineering is effective, efficient and attractive, especially in the field of design technology machine element

The specific objectives of this research are:

(1) Produce teaching materials based on Indonesian National Qualifications Framework in technical skills competencies in the field of machine element design technology through needs analysis.

(2) Produce teaching materials based on Indonesian National Qualifications Framework in technical skills competencies in the field of machine element design technology through limited scale field trials to produce, main products.

Technical skills in machine element design technology is a component of the subjects in the Engineering Study Program in Mechanical Engineering in accordance with the content standards for elementary and secondary education units. In the preparation of the Education Study Program curriculum

Mechanical Engineering subjects are divided into three groups, namely normative, adaptive, and productive including components of vocational competence. One component of 
technological vocational competence is the design of machine elements. The development of machine element design technology has brought revolutionary changes in the construction industry, both through manual and digital techniques. The development of this machine element design technology requires the availability of learning component components in institutions, education that is always relevant to the ever-growing demands of the business / construction industry. One of the efforts made by the Indonesian government in the effort to prepare graduates for formal education that are relevant to these needs is to develop a curriculum based on the Indonesian National Qualifications Framework in accordance with the formal education grade. For this reason, the provision of teaching materials based on the Indonesian National Qualifications Framework is one of the alternative educational and vocational technology services in solving human resource development problems, especially the institutions producing teachers in vocational schools.

Management of competency-based curriculum learning is compiled and developed by the teacher in the 2013 curriculum (K-13), basically it is new. That is, for teachers who in the early stages still demand a lot of attention from all parties concerned.

Management and implementation of K-13 cannot be separated from various aspects of learning and the factors that influence it, from the concept to the implementation, so that the learning objectives can be achieved well. One of the problems faced in K-13 in addition to this new policy has also been taken with regard to the development and implementation in the classroom, namely the lack of availability of teaching materials that are relevant to the needs of employment and future projections. This is due to the lack of competency of the teacher to translate training materials / materials into classroom learning strategies, causing problems in the process and learning outcomes of students.

To answer the above problems, it can be done through the development of teaching materials based on Indonesian National Qualifications Framework, especially in the field of machine element design technology. Many teaching materials in the vocational field of machine element design technology have been and are being developed at this time, with the aim that students' knowledge and skills increase. However, from the survey conducted by the researcher, the existing teaching materials have not yet reached the level of vocational competence desired in other words not in accordance with the desires of the job market.

Thus it is necessary to develop teaching materials that are relevant to future job needs and projections or based on Indonesian National Qualifications Framework, which can be used as a source of learning by students with self directed so that the learning process in the classroom is effective, efficient and empowered pull in achieving learning goals or improving student learning outcomes in vocational competencies machine element design technology. This requires that the institutions that produce educators or teachers in vocational schools must always be relevant to competency, in this case the students of the Engineering Education Study Program as prospective teachers in Vocational High Schools.

The scope of the design of machine elements includes, welding, shaft and pegs, bearings, couplings, belts, chains, and gears. Seeing the extent of material in this study is limited to welding.

\section{Literature Review}

Competence is the knowledge, skills and basic values that are reflected in the habit of thinking and acting. (Depdiknas, 2002).Competence is "being able to perform whole work 
roles, to the expected in employment in real working environment standards" (Burke, 1989). From this definition, there are three competency criteria: a). able to carry out the entire tasks of the workforce, more than having the skills or work tasks that are specific; b). in accordance with the standards expected in work; c). in real work environments that put pressure on and relate to all work and actual variations of work.

The SCANS report identifies 5 (five) competencies and 3 (three) basic parts someone's skills and quality to be able to handle work, namely: The five competencies: (a) resources: identifies, plans, and allocates resources (b) interpersonal: works well with others; (c) information: acquires and uses information; (d) systems: understands complex interrelationships; (e) technology: works with a variety of technologies. The three-part foundation consists of: (a) basic skills: reads, writes, performs arithmetic and mathematical operations, listens, and speaks effectively; (b) thinking skills: thinks creatively, make decisions, solves problems, visualizes, knows how to learn, and reasons; (c) personal qualities: displays responsibilities, self-esteem, sociability, self-management, integrity, and honesty (Huitt, 1999).

Competence is a basic characteristic consisting of skills, knowledge and other personal attributes that are able to distinguish someone from performing and not performing. Spencer \& Spencer classify competencies into basic characteristics, causal relationships and reference criteria as follows: 1) Basic characteristics are competence as part of personality individuals and can predict behaviour in situations and tasks, namely: a). motive as encouragement from person consistently to do an action; b). nature / character, namely physical characteristics and a consistent response to certain situations or information; c) self-concept, namely attitude values or an individual's image; d). knowledge, that is information that someone has for certain fields; and e). skills, namely the ability to carry out tasks physically or mentally. 2). Causal relationships are competencies that cause and predict behaviour and performance. Motivation, character / character competence and self-concept can predict the behaviour actions that are on finally it can predict performance results. 3). Reference criteria are the most critical competencies that can differentiate competencies with high or average performance(Spencer \& Spencer, 2008). Thus vocational competence is a form of one's ability and skill to carry out the whole vocational tasks in accordance with the standards expected in a real work environment.

Technical skills as the ability to apply specific knowledge, methods, or techniques in a particular area of specialization(Stoner James A. F., Freeman R. Edward, and Gilbert, 2003). This skill is an understanding and ability to do work activities related to specific fields or specific jobs. Technical skills are usually more related to other hand or physical skills.

In the field of machine element design, Okumura argued that technical skills in machine element design technology are actions to carry out metallurgical bonds on metal or metal alloy joints carried out in a molten state of several metal rods using heat energy through a procedure and technique which is done by hand (Okomura, T. dan Wiryosumarto, 2004). Also called it motorbike skill which is adaptive, because it combines several motoric movements in designing machine elements (Singer, 1975).

From the several definitions given by these experts, what is meant by technical skills in this study is the application of specific knowledge, procedures, and techniques in a particular area of specialization, which, related to psychomotor skills.

A learning design procedure, starting from identification, development, evaluation and ending with revisions (Twelker, 1972). Instructional materials were prepared based on learning strategies used(Harmon, 1982). Three types of model development to determine 
which are appropriate and appropriate to be used, namely: (1) an inductive model, which departs from the experience of current student behaviour, then grouped, compared, developed and finally evaluated for revision, (2) deductive model, beginning with the determination of general objectives, determining criteria, looking for links between existing elements / partners, data collection, formulation of specific objectives, developed and implemented, then evaluated and revised, ( 3 ) classic models, starting with some general requirements of objectives, program development, program implementation, then evaluated and revised (Kaufman \& English, 1979).

The University Consortium for Instructional Development and Technology (UCIDT) presents a model that can be applied for the development of learning. The University Consortium for Instructional Development and Technology (UCIDT) presents a model that can be applied for the development of learning. The model includes 3 (three) stages: definition, development and evaluation, divided into 9(nine) with 3 (three) steps and are interrelated with each other, namely::

Level I. Definition. Step I. Identification of the problem. In this first step it is done is the identification of problems, namely the gap between expected and existing. More specifically, determine the conditions, what and what should be achieved by students. The second step is the analysis of the situation, namely in what environment learning is organized, including students, learners (teachers), managers, and learning resources or materials. The third step is the management of management, namely the leader executor responsible and carrying out communication and other authorities. The fourth step, as part of the development stage is identification of goals. The stages of learning development begin by identifying specific learning goals, if achieved, then the problem in the first step will be solved. In the formulation of objectives must be stated: who is the participant or learners (Audiences), what behaviour can be done after the program is finished, under what conditions they are formed, and the level of expertise achieved. The fifth step is a special method or learning methods used to achieve goals. The sixth step is construct a blueprint or prototype, which is the components used, such as teaching preparation, exam materials, and specific guidelines and program evaluation. The seventh step is to test the prototype. The evaluation stage begins by testing each component of the program. This initial trial was carried out in a small sample and observations were held to see the presentation. Student comments are made as an assessment of what they participants have learned. The eighth step is the analysis of results. Data collected in the seventh step determines the significance of the extent of the contribution given by each component to the achievement of goals, useful or not. The final step is implementation / revision. Program improvement is done by looking at the achievement of certain goals, by reassessing the contribution of learning components to the achievement of goals (Molenda \& Rice, 1979).

The results achieved through preliminary studies funded by the Higher Education in the Competitive IX Research, have been conducted as product development research to find a learning model of psychomotor skills for training the Ministry of Manpower BLK / KLK in an effort to improve the quality of labour, as follows: 1) The basic components of the learning model psychomotor skills with whole method. 2) The basic component of the learning model of psychomotor skills with partial training (part method). The results of this study indicate that using an effective whole exercise model for psychomotor skills that has a simple movement and an effective training model for psychomotor skills that have complex movements. The results of research conducted by Napitupulu, at al found that by developing teaching materials based on the development of interactive multi-media based learning models, it can improve vocational competency of Construction Technology Vocational students (Napitupulu \& Julaga, 2014). 


\section{Methodology}

This research uses development research methods. Performed directly by collecting descriptive data that processes and analyse data inductively. To produce operational products, namely learning models with computer-based vocational tools to improve teacher teaching competencies that are effective, efficient and attractive, a research and development cycle process is known as "the R \& D cycle" (Gall, Gall, \& Borg, 2007). In this study, survey methods were used through needs analysis, trial methods through procedures (a) expert reviews, (b) one-on-one trials, (c) small group trials, and (d) limited scale field group trials .The population of this study were all Mechanical Engineering Education Study Program students who took machine element design courses. This sampling uses purposive techniques. Data collection techniques used in this study are questionnaire techniques and interview techniques, as well as documentation techniques to capture data on needs analysis activities, questionnaire techniques to capture data about the response of respondents and students on expert and validation activities on one-on-one trials and group trials. small, and testing techniques and observations on field trial activities are limited. Data analysis techniques used were (1) descriptive analysis to describe data from needs analysis and expert validation as well as one-on-one and small group trials. (2) t test to find out the difference in the effectiveness of the model for limited and wide-scale field testing.

\section{Result}

The finding of study are:

1) The quality of teaching materials according to expert material is presented in Figure 1 below:

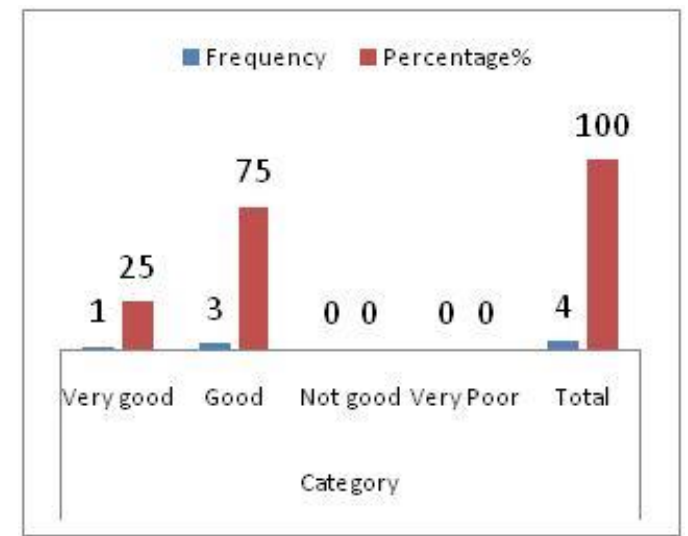

Fig. 1. The Quality of Material According to Expert Teaching Material

2) The One To One Try Out

The quality of teaching materials in One To One Try Out presented in Figure 2 below: 


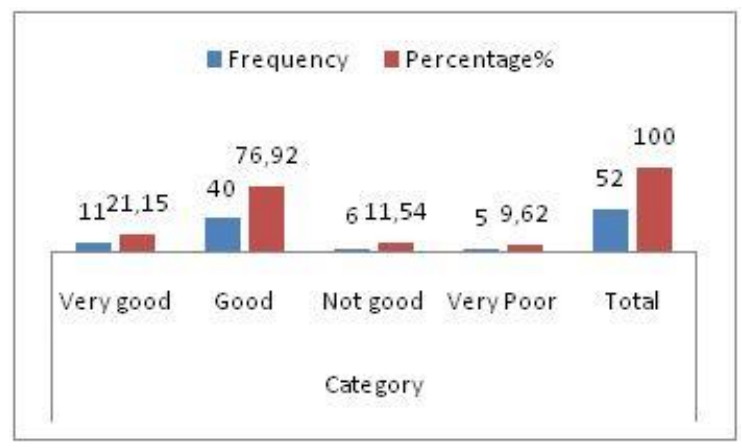

Fig. 2. The Quality of Teaching Materials According to in One to One Try Out

3) The Small Group Try Out

The quality of teaching materials in the small group try out presented in Figure 3 below:

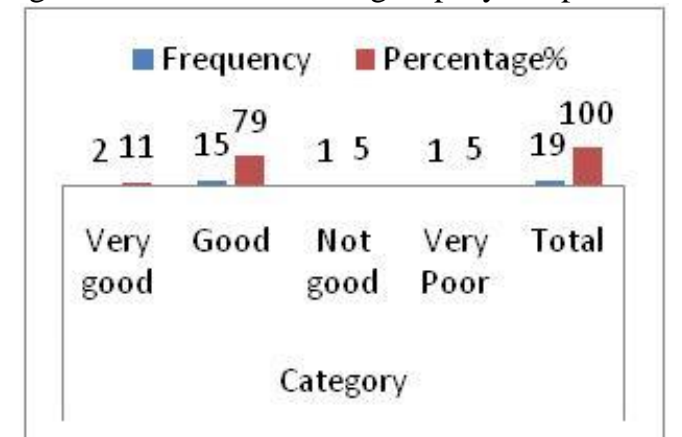

Fig. 3. The Quality of Teaching Materials in the Small Group Try Out

\section{Discussion}

From the description above shows that the quality of teaching materials according to the four material experts presented in Figure 1 shows that one person $(25 \%)$ stated very well three people $(75 \%)$ stated good. Then The One To One Try Out presented in Figure 2 shows eleven students $(5 \%)$ stated very well 40 students $(76.69 \%)$ said well, six students $(11.54 \%)$ said that they were not good and five students $(4.62 \%)$ stated very poor. Furthermore. the Small Group Try Out presented in Figure 3 shows two students (11\%) stated that very well 15 students $(79 \%)$ stated well, one student $(5 \%)$ stated that they were not good enough and one student $(5 \%)$ stated that they were not very good.

The findings of the study were: (1) the quality of teaching materials seen from good educational technology experts $(75.00 \%),(2)$ in one to one trials showed that the product was good $(76.69 \%)$, (3) in Small group trials showed that the product was good $(75.0 \%)$, The findings in this study are in accordance with research that has been done and in line with the theoretical framework that has been built. 


\section{Conclusion}

Based on the result of research and discussion, it can be concluded:

The quality of instructional material viewed from the expert in educational technologies is good. In the one to one try out indicated that the product is good .In the small group try out indicated that the product is good.

\section{Recommendation}

Based on the results obtained in this study, the development of teaching materials in accordance with the Indonesian National Curriculum Framework is needed to evaluate the performance and effectivities of the Instructional Material.

\section{Acknowledgements}

Thank you to the State University of Medan and the Ministry of Technology Research and Higher Education, the Research Institute of Medan State University, which has funded this research in the Medan State University Budget Implementation List (DIPA), in accordance with the Contractual Agreement SP Number DIPA-000574 / UN33 I KU I 2018, March 22, 2018

\section{References}

[1] Burke, J. W.: Competency based education and training. Psychology Press. (1989)

[2] Depdiknas.: Kurikulum Berbasis Kompetensi. (B. D. Puskur, Ed.). Jakarta. (2002)

[3] Gall, M. D., Gall, J. P., \& Borg, W. R.: Educational Research: An Introduction. New York: Person Education. Inc. (2007)

[4] Harmon, P..: The design of instructional materials. Journal of Instructional Development. Vol. 6 (1982)

[5] Huitt, W.: The SCANS report revisited. Paper Delivered at the Fifth Annual Gulf South. (1982)

[6] Kaufman, R. A., \& English, F. W.: Needs assessment: Concept and application. Educational Technology. (1979)

[7] Molenda, M., \& Rice, J. M.: Simulation Review: The Diffusion Simulation Game. Produced and distributed by the University Consortium for Instructional Development and Technology (UCIDT). Syracuse University@. Simulation \& Games. Vol. 10. Pp. 459-467. (1976)

[8] Napitupulu, E., \& Julaga, S.: The Instructional Model Development Based on Interactive Muledia on Technical Mechanics Competence of Vocational High School Students of North Sumatera Province. International Journal of Education and Research. Vol. 2. pp. 1-10. (2014)

[9] Okomura, T. dan Wiryosumarto, H.: Teknologi Desain Elemen Mesin Logam (Edisi 5.). Jakarta: Pradnya Paramita. (2004)

[10] Singer, R. N.: Motor learning and human performance: An application to physical education skills. Macmillan. (1975)

[11] Spencer, L. M., \& Spencer, P. S. M.: Competence at Work models for superior performance. John Wiley \& Sons. (2008) 
[11] Stoner James A. F., Freeman R. Edward, and Gilbert, J. D. R.: Management (Sixth Edition). (I. BookVistas (New Delhi, Ed.) (Sixth Edit). New Dehli: Pearson Education 0. (2003)

[12] Twelker, P. A.: The Systematic Development of Instruction: An Overview and Basic Guide to the Literature. (1972) 